\title{
Rules of Thumb for Evaluating Preferential Trading Arrangements: Evidence from Computable General Equilibrium Assessments
}

\author{
Glenn W. Harrison, University of Central Florida \\ Thomas F. Rutherford, University of Colorado \\ and
}

David G. Tarr, the World Bank*

\section{Non-Technical Abstract}

Most interesting results on the welfare effects of regional arrangements are ambiguous at a theoretical level. Many questions only have quantitative answers that are specific to the particular structural features of the economy and the policy considered. Thus, to determine the impact of prospective regional arrangements governments often rely on a quantitative evaluation. Usually at the request of client governments of the World Bank, we have implemented many computable general equilibrium (CGE) models to inform policy-makers. We summarize the main conclusions we draw from these studies.

Our principal conclusions are:

(i) countries excluded from a Preferential Trade Arrangement (PTA) almost always lose;

(ii) market access is a key determinant of the net benefits of a PTA;

(iii) with a Free Trade Agreement (FTA) the external tariff can be lowered such that a poor FTA becomes attractive;

(iv) for Southern countries, North-South agreements offer a beneficial increase in competition in their home markets, and involve little increase in the supply price of Northern country sales in Southern countries;

(v) multilateral trade liberalization results in significantly larger gains to the world than the network of regional arrangements;

(vi) for individual countries without high protection, "additive regionalism" will likely result in substantially larger gains than unilateral trade liberalization;

(vii) tax replacement requirements reduce the set of desirable regional arrangements;

(viii) trade taxes are often an inefficient source of tax revenue;

(ix) trade liberalization should be expected to be pro-poor in developing countries, but results will be diverse at the household level so safety nets are important; and

(x) we do not expect dynamic effects to reverse conclusions regarding regionalism.

JEL categories: F15, F02, C68.

Ketywords: Preferential Trade Integration, Computable General Equilibrium, welfare gains.

*The views expressed are those of the authors and do not necessarily represent those of the World Bank or its Executive Directors. 


\title{
Rules of Thumb for Evaluating Preferential Trading Arrangements: Evidence from Computable General Equilibrium Assessments
}

\author{
Glenn W. Harrison, Thomas F. Rutherford and David G. Tarr
}

Most interesting results on the welfare effects of regional arrangements are ambiguous at a theoretical level. Many questions only have quantitative answers that are specific to the particular model and policy considered. Thus, to determine the impact of prospective regional arrangements governments often rely on a quantitative evaluation. Usually at the request of a government involved, we have implemented a number of computable general equilibrium (CGE) models to inform policy-makers. ${ }^{1}$ We summarize the main conclusions we draw from these studies, focusing on applications in the Americas.

These conclusions are drawn from a number of model variants, including: perfect and imperfect competition; comparative static, comparative steady-state and dynamic; small open economy and multi-region; and representative consumer and multi-household. Despite the fact that we have found many of these results mentioned below repeatedly in our numerical work, and frequently undertaken piecemeal and systematic sensitivity analysis to identify the source of the results, we characterize these conclusions as rules of thumb. ${ }^{2}$ We acknowledge that there are modeling variants or parameter specifications where these rules of thumb may not hold.

\section{Countries excluded from a PTA almost always lose.}

Beginning in the mid 1990's, countries in Latin America have entered into a "spaghetti bowl" of PTAs. Considering each agreement on a pair-wise basis, excluded countries almost always lose from such arrangements. The obvious explanation is that the partner countries have preferred access to the markets of the included countries, which reduces demand for the exports of excluded countries into the markets of the PTA.

In Table 1 we collate some results to illustrate a number of points. These calculations are based on the 1998 tariff of Chile of 11\%. With our central elasticities we estimate that excluded countries as a whole lose US\$169 million per year from a FTA between Chile and MERCOSUR, but they lose US\$384 per year from an agreement between Chile and NAFTA. ${ }^{3}$

* University of Central Florida, University of Colorado and the World Bank, respectively. The views expressed are those of the authors and do not necessarily represent those of the World Bank or its Executive Directors.

${ }^{1}$ This includes work in Chile, Brazil, Morocco, Tunisia, Turkey, Iran and Kyrgyzstan.

${ }^{2}$ These are rules of thumb for welfare evaluation of these agreements, and thus are different from the rules of thumb suggested by Schiff and Winters [2003, ch. 9]. The latter are designed to maximize the benefits or minimize the costs of the agreements.

${ }^{3}$ Column 4 for Japan is an interesting exception. In this case, Chile adds an FTA with the EU to its network of FTAs with MERCOSUR and NAFTA. This illustrates that it is possible that an excluded country (here, Japan) can gain from a PTA from which it is excluded if one or more of the partner countries (here, 


\section{Market Access is a key determinant of the net benefits of a PTA.}

From Table 1 we see that Chile's agreement with MERCOSUR would induce losses for Chile. On the other hand, the FTA between Chile and NAFTA benefits Chile. We have shown that Chile would lose even from a FTA with NAFTA without preferred access in one or two key agricultural sectors in the United States. This shows that if we only consider trade creation versus trade diversion effects in the home market of Chile, both of these agreements are immizerising for Chile with our central elasticity assumptions. Agreements with the large "Northern" markets typically offer more market access, and from this factor alone agreements with Northern partners are more likely to be beneficial than agreements with Southern partners.

\section{With a FTA the external tariff can be lowered such that a poor FTA becomes attractive.}

With its 11\% uniform tariff as of 1998, we estimate that Chile would lose from a FTA with MERCOSUR. But Harrison, Rutherford and Tarr [2002] (HRT) calculate that Chile will gain from a FTA with MERCOSUR with its present $6 \%$ uniform external tariff. This suggests that, for countries that wish to liberalize trade, one significant advantage of a FTA over a CU is that the FTA does not prohibit the country interested in liberalizing its trade policies from doing so. The CU, on the hand, requires agreement on a common external tariff.

Moreover, the CU may impose a diverse tariff structure on a country that has a less distortionary uniform tariff. HRT [2002] found that if Chile had accepted the invitation to join the MERCOSUR CU, its losses would have exceeded the losses we estimated from the FTA with an $11 \%$ tariff. Michalopoulos and Tarr [1998] noted that Kyrgyzstan also had a uniform 10\% tariff when it was invited to participate in a CU with Russia, Kazakhstan and Belarus. But the external tariff of this CU had zero tariffs on most products produced by Kyrgyzstan and high tariffs on products produced in Russia. Thus, the Kyrgyz would have borne most of the trade diversion costs of the CU.

\section{For Southern countries, North-South agreements offer a beneficial increase in competition in their home markets, and involve little increase in the supply price on Northern country sales in Southern countries.}

We estimated the impact on developing countries of entering into a PTA with a large Northern region in several cases (e.g., EU-Morocco, EU-Turkey, EU-Tunisia, and Chile-NAFTA). We find that the Southern country would gain from the agreement in all these cases. Market access is important, as noted above. But it is also important that the Northern countries are large in relation to the size of the Southern partner in these agreements; consequently Northern partners provide additional supply to the Southern markets without raising their supply price. Even Northern

the EU) is a significant competitor with the excluded country in third country markets (here, the Rest of the World). Since the EU diverts sales from third country markets to Chile, the excluded country (Japan) would experience a terms of trade gain in the third country markets that could more than compensate for the terms of trade loss in the partner countries. 
countries can benefit from increased competition from regional arrangements with other Northern countries: HRT [1997a] find that the gains from the single market in the European Union are more than doubled due to the increased competition the single market will bring to European Union markets.

On the other hand, we estimated the impact of several South-South arrangements on partner countries. The results here are much more mixed. Examples of negative arrangements include Chile losing from an agreement with MERCOSUR; Kyrgyzstan losing from a customs union with Russia, Belarus and Kazahkstan; and Cameroon losing from the preferential trade aspects of its customs union arrangement in the Central African Economic and Monetary Community. Bakoup and Tarr [2000] show that the increase in the supply price due to increased trade with small partner countries is crucial to the conclusion that Cameroon will not benefit from the preferential tariff reduction.

\section{Multilateral trade liberalization results in significantly larger gains to the world than a network of regional arrangements.}

Largely because of the trade diversion effects on both included and excluded countries, most regional arrangements we have studied result in small gains or losses to the world as a whole. We find that multilateral trade liberalization results in global gains many multiples of the gains from the typical regional arrangement we have examined. In only one case did we find substantial gains to the world - we estimate that a FTA of the Americas plus a MERCOSUR-European Union agreement will yield global gains of $\$ 46$ billion p.a. in our central elasticity case in HRT [2003]. But even this is still several multiples less than our estimated gains to the world of free trade under the same set of elasticities. ${ }^{4}$

\section{For individual countries without high protection, "additive regionalism" will likely result in substantially larger gains than unilateral trade liberalization.}

Gains from preferential access. Several countries, led by Chile, have adopted a strategy of negotiating free trade agreements with all significant trading partners. We called this strategy additive regionalism; the Office of the U.S. Trade Representative, in a fit of marketing brilliance, called it “competitive liberalization." In HRT [2002] we estimate that Chile's strategy of individually negotiating an FTA with each of its significant trading partners results in gains to Chile many multiples of its gains from unilateral trade liberalization. In part this is because Chile starts, in our analysis, with a relatively undistorted most favored nation trade regime of an $11 \%$ uniform tariff (now 6\%). We estimate that unilateral trade liberalization will result in gains to Chile of about 0.1 of a percentage point of its GDP. Moreover, in the limit a network of FTAs eliminates trade diversion costs, since there can be no trade diversion in the home market if there are agreements with all

\footnotetext{
${ }^{4}$ Based on the estimates of Reidel [1988], in our multi-region trade models we use elasticities of substitution in import demand several times those employed in most CGE models. As a consequence our models are not dominated by high terms of trade effects (so countries will be expected to gain from unilateral trade liberalization except for very low tariff levels), and trade diversion effects are larger. This significantly contributes to our results for multilateral trade liberalization and for regional arrangements. We argued in HRT [1997b] that the choice of elasticities is crucial to explaining different results across competing models of the impact of the Uruguay Round.
} 
partners. In addition, FTAs bring preferred market access and terms of trade gains that are not obtained with unilateral trade liberalization. Preferred access to highly protected markets can yield very large gains if it can be negotiated. The gains to Chile could be as high as $8 \%$ of GDP if it succeeded in negotiating FTAs with all the regions in our Table 1 without product restrictions. More dramatically, HRT [2002] estimate that Uruguay would gain an enormous 44\% of its GDP from a MERCOSUR-European Union FTA that included free trade in the highly protected agricultural products of the EU.

Exceptions and Antidumping. On the other hand, if agriculture is excluded from a MERCOSUR-EU FTA, instead of 44\% Uruguay would obtain only 1\% of its GDP. In practice, regions may exclude their most highly protected sectors from regional agreements. For example, to date, the EU has provided very little preferred market access in agriculture in its network of Mediterranean agreements. This has been a great disappointment to its partner countries, especially to Morocco, which proposed this kind of arrangement with the hope of more agricultural access; and Chile and Brazil are concerned that antidumping policies may significantly limit the potential gains from a FTA of the Americas. So the large potential gains from preferred access in regional arrangements may be illusory in practice.

\section{Tax replacement requirements reduce the set of desirable regional arrangements.}

Regional arrangements involve a loss of tariff revenue, since partner country imports enter tariff free and trade diversion away from third countries involves an additional loss of tariff revenue on third country imports. In order to replace revenue, the government will have to employ alternate taxes. The use of alternate replacement taxes, however, typically involves the creation of distortions that should be weighed in the analysis as to whether to participate in a regional arrangement or not. For example, the value-added tax (VAT), which is one of the least distortionary replacement taxes, will still impose distortions in practice. Even when the legal rate of VAT is identical across sectors, the VAT will be collected at very different rates across sectors and will impose intersectoral distortions. Agriculture and many services sectors typically pay lower collected VAT rates due to tax evasion. In Chile, for example, the legal value added tax rate is $18 \%$ across all sectors, but the aggregate collected rate for the economy is about $9 \%$, with the collected rate varying across sectors from $2 \%$ to $18 \%$. We calculate that the VAT in Chile involves a "marginal cost of public funds" (MCF) of $7.6 \%$. That is, consumers and producers would have to be taxed 1076 pesos through the VAT for the government to receive 1000 pesos. The 76 pesos are the distortion costs of the VAT, and a welfare loss to the Chilean economy.

It follows that regional arrangements that are only marginally beneficial under the assumption of lump sum distortionless tax replacement may be welfare reducing when the additional welfare cost of tax replacement is taken into consideration. In our GE framework, with a government budget constraint, the economic link between domestic tax reform and foreign trade tax reform is unavoidable.

\section{Trade taxes are often an inefficient source of tax revenue.}

HRT [1997b][2002] estimated the MCF from the Chilean tariff at 18.5\%. That is, consumers and producers would have to be taxed 1185 pesos through the tariff for the government to receive 
1000 pesos. Despite the fact that the Chilean tariff is uniform across all sectors, and therefore does not impose inter-sectoral distortions, it has a higher MCF than the VAT. The reason is that the tariff discriminates geographically, favoring domestic import competing sectors versus imports (and implicitly taxing exports). By the standards of trade taxes, the low Chilean uniform tariff imposes relatively few distortion costs. Nonetheless, even this trade tax imposes more distortion costs than an inefficient VAT.

\section{Trade liberalization should be expected to be pro-poor in developing countries, but results will be diverse at the household level so safety nets are important.}

Although cross-country econometric work has found that open trade is good for the poor (Dollar and Kraay [2001]), most of the early efforts by CGE modelers to identify the links between trade policy and poverty were plagued by data problems, such as those discussed by HRT [2003]. In the case of Brazil, however, HRT and Gurgel [2003] estimate that most of the trade policy options under consideration result in a distribution of the gains to the different households that is progressive, so that the poorest households experience the greatest percentage increase in their incomes. In fact, they estimate that the poorest households will gain about 3 to 4 times the average for the Brazilian economy. This is because, although Brazil has dramatically liberalized its trade policy in the past 10 years, vestiges of its import substitution industrialization policies remain: capital-intensive manufacturing sectors remain the most highly protected sectors of the economy. Thus, trade policy changes in Brazil tend to shift resources from capital-intensive manufacturing toward unskilled labor-intensive agriculture and less capital-intensive manufacturing, thereby inducing an increase in the wage of unskilled labor relative to other factors of production.

Many analysts have found that it is factor income changes, and not expenditure patterns, that are crucial to determining the outcome on the poor from trade policy changes. Among factor income changes, the wage of unskilled labor is the most important determinant of the impact of trade policy changes on the poor. So an increase in the relative wage of unskilled labor should result in an increase in the incomes of the poorest households.

In developing countries we might expect that the labor intensive sectors that are important to the poor will be disfavored by the structure of protection, so that the medium to long run effects of these trade reforms would be positive for the poorest households. In practice, there will be cases where the poor may not gain more than proportionately relative to the average for the economy. But growth from open trade regimes should be expected to lift the majority of the poor households. We emphasize, however, that at a very dis-aggregated level some poor households (like maize farmers in Mexico) could lose, especially in the short run. This emphasizes the need for effective safety net policies to be in place. $^{5}$

${ }^{5}$ Jensen and Tarr [forthcoming] have shown that incomes of the poor in Iran would double or triple if commodity subsidies were converted to non-targeted direct income support. Of course, targeted income support for the poor would be even more beneficial for them. 


\section{We do not expect dynamic effects to reverse conclusions regarding regionalism.}

Rutherford and Tarr [forthcoming] developed a fully dynamic small open economy model of Chile with constant returns to scale in all sectors. They show that simply adding dynamics to a perfectly competitive constant returns to scale model will not change the welfare results in any significant way. The reason is that trade liberalization that induces a larger capital stock does not necessarily improve welfare since the capital stock is already optimized on the steady state path based on the consumption-investment tradeoff. Thus, it is not the case that "any kind of dynamics" is sufficient to produce larger gains from trade liberalization, or produce larger gains from a regional arrangement. In particular, the losses from the Chile-MERCOSUR agreement are not eliminated, and are in fact slightly larger.

Rutherford and Tarr [2002] show that when learning and technology effects are taken into account endogenously in a fully dynamic model with increasing returns to scale, the estimated gains from trade liberalization will be many multiples of the estimated gains from a static model. It does not follow, however, that the estimated gains from PTAs would be much larger when learning and technology transfer effects are incorporated, even if the static effects are dominated by trade diversion. In ongoing work, we find that there is a dynamic form of trade diversion in models that allow for productivity impacts and technology transfer from imports. That is, while regional preferences will encourage additional varieties and technology imports from regional partners, it will discourage additional varieties and technology imports from the rest of the world. As pointed out by Coe et al. [1997], one should question how technologically advanced and large the prospective partner really is. For prospective partners such as the European Union or NAFTA, the additional technology imports are likely to be sufficiently large to offset the losses from the rest of the world. ${ }^{6}$ In this case the dynamic model will produce gains from regional arrangements with technologically advanced partners that are several times the estimated gains from static models. On the other hand, if a PTA is made with a technologically less advanced region, the diversion of new technologies or varieties from the rest of the world could hinder productivity advances in the home country. On balance, growth and welfare may be reduced and may result in losses several multiples of the estimated static losses.

${ }^{6}$ Schiff and Wang [forthcoming] find evidence that technology spillovers from trade with NAFTA are a lot stronger than those with the EU. 


\section{References}

Bakoup, Ferdinand; and Tarr, David G., "The Economic Effects of Integration in the Central African Economic and Monetary Community: Some General Equilibrium Estimates for Cameroon," African Development Review, 12(2), December 2000.

Coe, David T.; Helpman, Elhanan, and Hoffmaister, Alexander W., "North-South R\&D Spillovers," Economic Journal, 107, January 1997, 134-149.

Dollar, David, and Kraay, Aart, "Trade. Growth and Poverty," Policy Research Working Paper 2615, The World Bank, 2001.

Harrison, Glenn W.; Rutherford, Thomas F., and Tarr, David, "Piecemeal Trade Reform in the Partially Liberalized Economy of Turkey,” World Bank Economic Review, 7, May 1993, 191-217.

Harrison, Glenn W.; Rutherford, Thomas F., and Tarr, David G., "Increased Competition and Completion of the Market in the European Community: Static and Steady-State Effects," Journal of Economic Integration, 11(3), September 1996, 332-365.

Harrison, Glenn W.; Rutherford, Thomas F., and Tarr, David G., "Economic Implications for Turkey of a Customs Union with the European Union," European Economic Review, 41(3-5), April 1997a, 861-870.

Harrison, Glenn W.; Rutherford, Thomas F., and Tarr, David G., "Quantifying the Uruguay Round," Economic Journal, 107(444) , September 1997b, 1405-1430.

Harrison, Glenn W.; Rutherford, Thomas F., and Tarr, David G., "Opciones de Política Comercial para Chile: una Evaluación Cuantitiva," Cuadernos de Economía, 34, August 1997c, 101-137.

Harrison, Glenn W.; Rutherford, Thomas F., and Tarr, David G., "Chile's Regional Arrangements and the Free Trade Agreement of the Americas: The Importance of Market Access," Policy Research Working Paper 2634, The World Bank, 2001.

Harrison, Glenn W.; Rutherford, Thomas F., and Tarr, David G., "Trade Policy Options for Chile: The Importance of Market Access," The World Bank Economic Review, 16 (1), 2002, 49-79.

Harrison, Glenn W.; Rutherford, Thomas F., and Tarr, David G., "Trade Liberalization, Poverty and Efficient Equity," Journal of Development Economics, 71, June 2003, 97-128.

Harrison, Glenn W.; Rutherford, Thomas F., Tarr, David G.; and Angelo Gurgel, "Regional, Multilateral and Unilateral Trade Policies of MERCOSUR for Growth and Poverty Reduction in Brazil," Policy Research Working Paper 3051, The World Bank, May 2003. Portuguese version forthcoming as "Politicas comerciais regionais, multilaterais e unilaterais do MERCOSUL para o crescimento economico e reducao da pobreza no Brasil," Pesquisa e Planejamento Econômico, 2003.

Jensen, Jesper, and Tarr, David, "Trade, Exchange Rate and Energy Pricing Reform in Iran: Potentially Large Efficiency Effects and Gains to the Poor," Review of Development Economics, forthcoming.

Michalopoulos, Constantine, and Tarr, David G., "Customs Unions in the Commonwealth of Independent States," Post-Soviet Geography and Economics, 38(3), March 1997, 125-143. 
Reidel, James, “The Demand for LDC Exports of Manufactures: Estimates from Hong Kong,” Economic Journal, 98, March 1988, 138-148.

Rutherford, Thomas F.; Rutström, E. Elisabet; and Tarr, David G., "L'Accord de Libre-Échange entre le Moroc et la CE: Une Evaluation Quantitative," Revue d'Economie du Developpement, 1994, 97-133.

Rutherford, Thomas F.; Rutström, E. Elisabet; and Tarr, David G., "Morocco's Free Trade Agreement with the EU: A Quantitative Assessment," Economic Modelling, 14(9), April 1997, 237-269.

Rutherford, Thomas; Rutström, E. Elisabet; and Tarr, David G., "A Free Trade Agreement Between the EU and a Representative Arab Mediterranean Country," in B. Hoekman and J. Zarrouk (eds.), Catching Up with the Competition: Trade Policy Challenges and Options for the Middle East and North Africa (Ann Arbor, MI: University of Michigan Press, 2000).

Rutherford, Thomas F., and Tarr, David G., "Trade Liberalization, Product Variety and Growth in a Small Open Economy: A Quantitative Assessment," Journal of International Economics, 56(2), March 2002, 247-272.

Rutherford, Thomas F., and Tarr, David G., "Chile's Regional Arrangements - Do the Results Differ with a Dynamic Model?" Integration and Trade, forthcoming; available at http://www.iadb.org/intal/ingles/i-default.htm.

Schiff, Maurice, and Wang, Yanling, "NAFTA, Technology Diffusion and Productivity in Mexico," Cuadernos de Economia, forthcoming.

Schiff, Maurice, and Winters, L. Alan, Regional Integration and Development (Washington D.C.: Oxford University Press and the World Bank, 2003). 
Table 1. The Welfare Impact of Chile's Additive Free Trade Agreements and Global Free Trade $\stackrel{a}{-}$

(Welfare gains in millions of 1995 U.S. dollars)

\begin{tabular}{|c|c|c|c|c|c|c|c|}
\hline \multirow[b]{3}{*}{ Country } & \multicolumn{7}{|c|}{ AGREEMENTS WITH: } \\
\hline & & $\begin{array}{c}\text { MERCOSUR } \\
\text { (1) }\end{array}$ & $\begin{array}{c}\text { NAFTA } \\
\text { (2) }\end{array}$ & $\begin{array}{c}\text { NAFTA \& } \\
\text { MERCOSUR } \\
\text { (3) }\end{array}$ & $\begin{array}{c}\text { NAFTA } \delta \\
\text { MERCOSUR } \\
\text { EU } \\
\text { (4) }\end{array}$ & $\begin{array}{c}\text { NAFTA \& } \\
\text { MERCOSUR } \\
\& E U \text { \& Rest of } \\
\text { S A } A^{b} \\
\text { (5) }\end{array}$ & $\begin{array}{c}\text { GLOBAL } \\
\text { FREE } \\
\text { TRADE } \\
\text { (6) }\end{array}$ \\
\hline & \multicolumn{7}{|l|}{$\underline{\text { Elasticity }}$} \\
\hline \multirow[t]{2}{*}{ 1. Chile } & central & -291 & 414 & 590 & 2090 & 3350 & 504 \\
\hline & (low) & $(-67)$ & $(149)$ & (239) & (1013) & (1318) & $(270)$ \\
\hline \multirow[t]{2}{*}{ 2. United States } & central & -7 & 51 & -29 & 138 & 60 & 19972 \\
\hline & (low) & $(-24)$ & $(306)$ & (231) & $(59)$ & $(-11)$ & (10833) \\
\hline \multirow[t]{2}{*}{ 3. Canada } & central & 5 & -20 & -22 & 23 & 49 & 243 \\
\hline & (low) & (4) & $(-15)$ & $(-13)$ & (14) & (19) & $(-2058)$ \\
\hline \multirow[t]{2}{*}{ 4. Mexico } & central & 13 & -58 & -44 & -11 & 15 & -4539 \\
\hline & (low) & (1) & $(-35)$ & $(-35)$ & $(-3)$ & $(0)$ & $(-3315)$ \\
\hline \multirow[t]{2}{*}{ 5. Argentina } & central & 63 & -1 & 222 & 264 & 147 & 1832 \\
\hline & (low) & $(44)$ & $(-18)$ & (54) & (54) & $(28)$ & $(1327)$ \\
\hline \multirow[t]{2}{*}{ 6. Brazil } & central & 214 & -42 & -171 & -161 & -70 & 3912 \\
\hline & (low) & $(108)$ & $(-36)$ & $(15)$ & $(-11)$ & $(-21)$ & $(1004)$ \\
\hline \multirow[t]{2}{*}{ 7. Central America } & central & 4 & -37 & -32 & -23 & -38 & 6112 \\
\hline & (low) & (3) & $(-21)$ & $(-21)$ & $(-29)$ & $(-36)$ & $(2680)$ \\
\hline \multirow[t]{2}{*}{ 8. Rest of So. America } & central & -34 & -56 & -95 & -73 & -2024 & 7456 \\
\hline & (low) & $(-28)$ & $(-39)$ & $(-75)$ & $(-90)$ & $(-376)$ & $(2110)$ \\
\hline \multirow[t]{2}{*}{ 9. European Union } & central & -184 & -156 & -336 & -88 & -200 & 207413 \\
\hline & (low) & $(-28)$ & $(-241)$ & $(-317)$ & $(156)$ & $(86)$ & $(88720)$ \\
\hline \multirow[t]{2}{*}{ 10. Japan } & central & -58 & -19 & -30 & 81 & -2 & 127664 \\
\hline & (low) & $(-30)$ & $(-48)$ & $(-69)$ & $(-76)$ & $(-91)$ & $(73711)$ \\
\hline \multirow[t]{2}{*}{ 11. Rest of the World } & central & 92 & -73 & -50 & -115 & 6 & 85111 \\
\hline & (low) & $(29)$ & $(-89)$ & $(-100)$ & $(-229)$ & $(-232)$ & (23348) \\
\hline \multirow[t]{2}{*}{ 12. Sum for Included Countries $\stackrel{c}{ }$} & central & -14 & 387 & 546 & 2255 & 1327 & \\
\hline & (low) & $(85)$ & $(405)$ & (491) & $(1282)$ & $(1043)$ & \\
\hline \multirow[t]{2}{*}{ 13. Sum for Excluded Countries ${ }^{d /}$} & central & -169 & -384 & -543 & -130 & -34 & \\
\hline & (low) & $(-73)$ & $(-492)$ & $(-582)$ & $(-424)$ & $(-359)$ & \\
\hline \multirow[t]{2}{*}{ 14. Sum over all countries } & central & -183 & 3 & 3 & 2125 & 1293 & 455680 \\
\hline & (low) & $(12)$ & $(-87)$ & $(-91)$ & $(858)$ & $(684)$ & (198626) \\
\hline
\end{tabular}

a/ All products included in agreements and lumpsum tax replacement.

Rest of SA is South America except for Chile, Argentina and Brazil.

Sum of the welfare impact for countries included in the agreement.

Sum of the welfare impact for countries excluded from the agreement.

Source: Model estimates by authors. 